\title{
IMPLIKASI PEMBERDAYAAN ORANGTUA DALAM MENGOLAH DAN MENYUSUN MENU MAKANAN TERHADAP PENAMBAHAN TINGGI BADAN ANAK PENDERITA STUNTING
}

\author{
Annisa Ridlayanti ${ }^{1)}$, Ariani Fatmawati ${ }^{1 *}$, Yusi Sofiyah ${ }^{12}$ \\ ${ }^{1)}$ Universitas Asiyiyah Bandung, Jl. K.H Ahmad Dahlan Dalam No.6 Bandung \\ e-mail: rianiners@gmail.com
}

\begin{abstract}
ABSTRAK
Stunting adalah salah satu masalah gizi yang sedang dihadapi dunia terutama negara miskin dan berkembang. Angka kejadian stunting di Indonesia pada tahun 2017 adalah sebesar 22,2\% atau sekitar 150,8 juta balita di Indonesia mengalami stunting. Tujuan dari penelitian ini adalah teridentifikasinya pengaruh pemberdayaan orang tua dalam menyusun menu makanan terhadap penambahan tinggi badan anak penderita stunting di Desa Jagabaya Kabupaten Bandung dan teridentifikasinya kebiasaan orang tua dalam mengolah dan menyusun menu makanan untuk anak. Rancangan yang digunakan dalam penelitian ini adalah quasi-eksperimen dengan desain the one group pretest-postest design. Jumlah sampel pada penelitian ini adalah 18 responden dengan waktu penelitian selama 3 bulan yaitu pada bulan Agustus-Oktober 2020. Hasil penelitian menunjukan bahwa terdapat pengaruh pemberdayaan orang tua dalam mengolah dan menyusun menu makanan terhadap penambahan tinggi badan anak penderita stunting ( $P$-value $0,00)$. Pemberdayaan orang tua dengan memberikan penjelasan dan contoh makanan akan berpengaruh terhadap peningkatan tinggi badan anak dengan stunting.
\end{abstract}

Kata Kunci: Anak, Pemberdayaan, Menu Makanan, Stunting

\section{ABSTRACT}

Stunting is one of the nutritional problems currently facing the world, especially in poor and developing countries. The incidence of stunting in Indonesia in 2017 was $22.2 \%$ or around 150.8 million children under five in Indonesia were stunted. The purpose of this study is to identify the influence of parental empowerment in preparing food menus on the increase in height of children with stunting in Jagabaya Village, Bandung Regency and to identify the habits of parents in processing and compiling food menus for children. The design used in this study was a quasi-experimental design with the one group pretest-postest design. The number of samples in this study were 18 respondents with a study period of 3 months, namely in AugustOctober 2020. The results showed that there was an effect of parental empowerment in processing and compiling food menus on the increase in height of children with stunting (Pvalue 0.00). Empowering parents by providing explanations and food samples will have an effect on increasing the height of children with stunting.

Keywords: Children, Empowerment, Food Menu, Stunting

Jurnal Kesehatan Holistic/ Volume 5/ Nomor 1/Januari 2021

(ISSN: 2548-1843, EISSN: 2621-8704) 


\section{PENDAHULUAN}

Stunting adalah gangguan pertumbuhan yang disebabkan karena kurangnya gizi sejak masa kehamilan sampai usia 24 bulan (Bloem et al., 2013). Batasan dari WHO terhadap angka kejadian kurang gizi adalah kurang dari 20\%. Angka kejadian stunting di Jawa Barat lebih tinggi dari nasional yaitu sekitar 32\% (Kemenkes, 2018). Di Kabupaten Bandung 7,61\% (TNP2K, 2017). Sementara di Desa Jagabaya kejadian stunting mencapai $51 \%$ dari total jumlah balita. Dampak stunting dapat meningkatkan angka kesakitan dan kematian, pertumbuhan dan perkembangan mental terhambat, terhambatnya perkembangan motorik akibat pertumbuhan otak tidak maksimal (Unicef, 2013). Dampak pertumbuhan stunting juga dapat mempengaruhi tingkat kecerdasan anak. Anak yang mengalami stunting akan mengalami turunnya prestasi disekolah dan berisiko mengalami penyakit degenerative (Picauly \& Toy, 2013), tingginya angka kegemukan (obesitas) pada anak(Timæus, 2012), rentan mengalami penyakit tidak menular (Unicef, 2013).
Tingginya angka kejadian stunting di Indonesia dipengaruhi oleh beberapa faktor diantaranya adalah laki-laki lebih berisiko, usia 6-59 bulan, berat badan lahir rendah. Faktor dari ibu diantaranya tinggi badan ibu, pendidikan ibu, tidak mengkonsumsi anti parasit saat hamil, keluarga tidak mampu, jumlah balita dalam rumah, BMI ibu rendah dan riwayat diare berulang dapat (Berhe et al., 2019), pola asuh makan dan keragaman pangan (Widyaningsih et al., 2018), tingkat asupan energi, rata-rata lama sakit, dan tingkat pendapatan keluarga (Setiawan et al., 2018).

Tanda-tanda anak yang mengalami stunting yaitu pertumbuhan fisik terhambat, biasanya anak menjadi lebih pendiam, tidak banyak melakukan eye contact, dan untuk jangka panjangnya pubertas terhambat serta penurunan dalam prestasi atau belajar.

Peran ibu dalam pemenuhan gizi dengan anak stunting adalah dengan memperhatikan kebutuhan gizi anak. Anak pra sekolah (usia 3-5 tahun) sudah mampu memilih makanan yang 
disukainya. Mereka adalah konsumen aktif. Kemampuan anak memilih makanan dipengaruhi oleh keadaan psikologis, kesehatan dan sosial anak. Pada usia ini kebutuhan zat gizi meningkat karena masih berada pada masa pertumbuhan cepat dan aktivitasnya tinggi (Rahayu \& Khairiyati, 2014). Anak-anak sudah memiliki pilihan terhadap makanan yang disukai termasuk makanan jajanan. Orang tua harus memperhatikan jumlah dan variasi makanan. Terutama berbagai macam pilihan makanan sehat dengan gizi seimbang. Kebutuhan energi untuk anak balita dengan stunting yaitu kalori, protein, karbohidrat, lemak, cairan dan vitamin, kalsium, yodium, zink, zat besi, asam folat, pemberian ASI dan MP-ASI(Wiyono, 2015).

Prinsip penyusunan menu balita yaitu menyusun menu seimbang dengan cara pada setiap menu hidangan harus mengandung kalori dari karbohidrat, protein, lema, di sempurnakan dengan vitamin dan mineral. Penyusunan menu balita yang baik dengan cara: memilih makanan yang cukup mengandung kalsium dan zat besi. Menu makanan balita ditentukan sesuai dengan pertumbuhan anak, kemampuan menerima rangsangan makan dan mencerna makanan. Dikelompokan menjadi makanan anak usia 1-3 tahun, dan makanan anak usia 3-5 tahun. Penyusunan menu balita harus mengacu pada angka kecukupan gizi (AKG). Terdapat beberapa waku makan yang diberikan pada balita supaya pola makan pada balita dapat lebih teratur, baik, dan dapat dikontrol supaya tidak kelebihan zat gizi.

\section{METODE}

Rancangan yang digunakan dalam penelitian ini adalah quasi-eksperimen dengan desain the one group pretestpostest design. Tempat penelitian dilakukan di Desa Jagabaya Kab. Bandung dengan waktu penelitian selama 3 bulan yaitu pada bulan Agustus-Oktober 2020.

Pemberdayaan orang tua yang diberikan berupa edukasi kesehatan mengenai cara mengolah dan Menyusun menu makanan. Metode edukasi melalui penyuluhan kesehatan 
dan praktikum demontrasi cara mengolah dan menyususn menu makanan sehari bagi anak balita penderita stunting. Pemberian edukasi dilakukan selama 3 hari. Penapisan klien dilakukan oleh peneliti, bidan desa setempat, dan dibantu oleh kader posyandu guna memperoleh data balita penderita stunting.

Instrumen pengumpulan data yang digunakan pada penelitian ini adalah lembar observasi tinggi badan balita dan form kuesioner yang berisi karakteristik responden yaitu usia gestasi, tinggi badan lahir, usia balita, jenis kelamin, jumlah anak, posisi balita dalam keluarga, pekerjaan orang tua, penghasilan orang tua, pendidikan orang tua, status pemberian ASI eksklusif, status imunisasi dasar, riwayat penyakit infeksi. Alat yang digunakan yaitu microtoise, KMS dan kit menu makanan.

Data yang sudah terkumpul kemudian dilakukan analisis dengan menggunakan analisis uji beda dua mean berpasangan dengan menggunakan uji beda 2 mean berpasangan (dependenAdapun apabila data tidak terdistribusi normal uji Wilcoxon Signed Rank Test bisa dijadikan uji alternatif dari uji pairing $t$ - test atau $t$ paired apabila data tidak terdistribusi normal. Wilcoxon Signed Rank Test ini merupakan uji nonparametriks untuk mengukur signifikansi perbedaan antara 2 kelompok data berpsangan yang berskala ordinal atau interval tetapi tidak terdistribusi normal(Hidayat, 2012).

Populasi dalam penelitian ini adalah seluruh balita yang ada di Desa Jagabaya Kab. Bandung. Besar populasi pada penelitian ini sebanyak 305 balita. Pemilihan sampel dengan menggunakan non probability sampling berupa consecutive sampling. Kriteria inklusi yaitu balita usia 24-59 bulan, mengalami stunting, TB/U $<-2$, memiliki KMS, anak kandung. Sementara kriteria eksklusi yaitu balita yang sedang sakit atau mempunyai penyakit yang gawat, memiliki kelainan kongenital atau cacat fisik. Untuk menentukan jumlah sampel 
dalam penelitian ini menggunakan rumus Supranto (Supranto, 2000).

\section{HASIL DAN PEMBAHASAN}

Hasil penelitian ini, disajikan dalan tabel sebagai berikut

Tabel 1

Karakeristik Responden Berdasarkan Usia Gestasi, Panjang Badan Lahir, Usia dan Jenis Kelamin Anak $(n=18)$

\begin{tabular}{lcl}
\hline Varabel & Frekuensi & Persentase \\
\hline Usia Gestasi & & \\
\hline 37 minggu & 8 & $44,4 \%$ \\
\hline 38 minggu & 6 & $33,3 \%$ \\
\hline 39 minggu & 4 & $22,2 \%$ \\
\hline $\begin{array}{l}\text { Panjang } \\
\text { Lahir }\end{array}$ & & \\
\hline 46 & & $5,6 \%$ \\
\hline 47 & 1 & $22,2 \%$ \\
\hline 48 & 5 & $27,8 \%$ \\
\hline 49 & & $44,4 \%$ \\
\hline Usia Balita & & \\
\hline $23-34$ bulan & 6 & $33,3 \%$ \\
\hline $35-45$ bulan & 9 & $50 \%$ \\
\hline $46-59$ bulan & 3 & $16,7 \%$ \\
\hline Jenis Kelamin & & \\
\hline Laki-laki & 10 & $55,6 \%$ \\
\hline Perempuan & 8 & $44,4 \%$ \\
\hline
\end{tabular}

Dari tabel 1 diketahui bahwa sebagian besar usia kehamilan balita adalah 37 minggu (44,4\%), panang badan lahir 49 cm (44,4\%0, usia balita 35-45 minggu (50\%) dan sebagian besar berjeis kelamin laki-laki $(55,6 \%)$.
Tabel 2

Karakeristik Responden Berdasarkan Jumlah anak di Keluarga, Pekerjaan Orang Tua, Penghasilan Orag Tua, Pemberian ASI Eksklusif, Status Imunisasi dan Riwayat Infeksi $(n=18)$

\begin{tabular}{ccc}
\hline Varabel & Frekuensi & Persentase \\
\hline Jumlah Anak & & \\
\hline 3 & 2 & $11,1 \%$ \\
\hline 4 & 5 & $27,8 \%$ \\
\hline 5 & 6 & $33,3 \%$ \\
\hline 6 & 3 & $16,7 \%$ \\
\hline 7 & 2 & $11,1 \%$ \\
\hline
\end{tabular}

Pekerjaan Orang

Tua

\begin{tabular}{lcl}
\hline Tidak Bekerja & 2 & $11,1 \%$ \\
\hline Buruh & 10 & $55,6 \%$ \\
\hline Pegawai Swasta & 5 & $27,8 \%$ \\
\hline Wiraswasta & 1 & $5,6 \%$ \\
\hline Pendidikan & &
\end{tabular}

Orang Tua

\begin{tabular}{|c|c|c|}
\hline SD & 10 & $55,6 \%$ \\
\hline SMP & 7 & $38,9 \%$ \\
\hline SMA & 1 & $5,6 \%$ \\
\hline \multicolumn{3}{|l|}{$\begin{array}{l}\text { Penghasilan } \\
\text { Orang Tua }\end{array}$} \\
\hline$<500.000$ & 3 & $16,7 \%$ \\
\hline $\begin{array}{l}500.000- \\
1000.000\end{array}$ & 8 & $44,4 \%$ \\
\hline$>1000.000$ & 7 & $38,9 \%$ \\
\hline $\begin{array}{l}\text { Pemberian ASI } \\
\text { Eksklusif }\end{array}$ & & \\
\hline $\begin{array}{ll}\text { Tidak } & \text { ASI } \\
\text { Eksklusif } & \end{array}$ & 13 & $72,2 \%$ \\
\hline ASI Eksklusif & 5 & $27,8 \%$ \\
\hline \multicolumn{3}{|l|}{ Status Imunisasi } \\
\hline Lengkap & 10 & $55,6 \%$ \\
\hline Tidak Lengkap & 8 & $44,4 \%$ \\
\hline \multicolumn{3}{|l|}{$\begin{array}{l}\text { Riwayat Penyakit } \\
\text { Infeksi }\end{array}$} \\
\hline Ada Riwayat & 12 & $66,7 \%$ \\
\hline $\begin{array}{ll}\text { Tidak } & \text { Ada } \\
\text { Riwayat } & \end{array}$ & 6 & $33,3 \%$ \\
\hline Jumlah & 18 & \\
\hline
\end{tabular}


Dari tabel 2 diketahui bahwa sebagian besar jumlah anak di keluarga adalah 5 orang $(33,3 \%)$, pekerjaan orang tua sebagai buruh $(55,6 \%)$, pendidikan orang tua $\mathrm{SD}(55,6 \% 0$, penghasilan orang tua $<\operatorname{Rp} 500.000$, tidak diberikan ASI eksklusif (72,2\%), status imunisasi lengkap $(55,6 \%)$ dan sebagian besar ada riwayat infeksi $(66,7 \%)$.

Tabel 3

Pengaruh Pemberdayaan Orangtua dalam Mengolah Dan Menyusun Menu Makanan terhadap Penambahan Tinggi Badan Anak Penderita Stunting $(\mathrm{n}=18)$

\begin{tabular}{cccc}
\hline Variabel & Mean & St.Deviasi & pValue \\
\hline Tinggi & - & 1,724 & 0,000 \\
Badan & 2,833 & & \\
\hline
\end{tabular}

Dari tabel 3 diketahui bahwa Pvalue $0,000 \quad(<0,05)$ yang berarti bahwa terdapat Pengaruh Pemberdayaan Orangtua Dalam Mengolah Dan Menyusun Menu Makanan terhadap Penambahan Tinggi Badan Anak Penderita Stunting.

Dalam penelitian didapatkan bahwa terdapat pengaruh pemberdayaan orang tua dalam menyusun makanan terhadap penambahan tinggi badan pada anak dengan stunting di desa Jagabaya Kabupaten Bandung (Pvalue:0,00). Gizi yang kurang dan stunting pada balita dapat menghambat tumbuh kembang anak yang akan berdampak negatif pada kehidupannya seperti kemunduran kemampuan intelektual, rentan terkena penyakit, penurunan produktivitas hingga kemiskinan dan risiko mengalami berat badan bayi lahir rendah (WHO, 2010). Reifsnider et al (2016) dalam penelitiannya mengatakan dengan metode intervensi Program Nutrisi Tambahan Khusus untuk Wanita, Bayi, dan Anak-anak (Women, Infant and Children) didapatkan hasil bahwa anak-anak memiliki kecepatan pertumbuhan yang lebih tinggi daripada anak-anak dalam kelompok kontrol dan Ibu yang menghadiri intervensi 5-8 kali mengalami peningkatan pertumbuhan pada anaknya dibandingkan yang menghadiri 0-4 kali $(\mathrm{p}=0,026)$. Penelitian (Utami \& Juliani, 2020) juga menunjukkan bahwa pemberian nutrisi berpengaruh terhadap penurunan kejadian stunting pada balita. Pemberian pendidikan kesehatan yang dilakukan pada penelitian ini 
ditunjukan bagi ibu dengan anak stunting. Rockers et al (2016) dalam penelitiannya didapatkan bahwa dengan intervensi dengan memberikan pendidikan kesehatan dan stimulasi responsive berpengaruh terhadap peningkatan berat badan (0,12 SD), tinggi badan $(0,15 \mathrm{SD})$ dan peningkatan fungsi motorik dan kognitif pada anak $(0,11$ SD). Penelitian lain dari Vazir et al (2013) mengatakan bahwa memberikan pendidikan kesehatan yang tepat tentang makanan pendamping dan strategi bagaimana memberi makan dan bermain secara responsif melalui kunjungan rumah akan meningkat asupan makanan, pertumbuhan dan perkembangan anakanak. Dari hasil penelitian didapatkan bahwa terdapat 18 anak dari total populasi 305 balita yang mengalami tinggi badan menurut umur di bawah standar dalam satu desa. Hanifah et al (2018) mengatakan bahwa prevalensi stunting meningkat dari 29,7\% pada tahun 2000 menjadi 32,6\% pada tahun 2014. Hal ini memperlihatkan bahwa jumlah angka balita dengan stunting setiap tahun mengalami meningkatan. Jika dilihat dari karakteristik responden, sebagian besar orang tua bekerja sebagai buruh dan pendidikan terakhir yang terbanyak adalah tamat SD (55,6\%) dan paling banyak berpenghasilan kurang dari 500.000 perbulan. Faktor risiko stunting salah satunya adalah keluarga dengan penghasilan rendah (Paudel et al., 2012), tersedianya makanan dan minuman sehat. Dalam penelitian didapatkan bahwa sebaigian besar responden memiliki riwayat penyakit infeksi (66,7\%), sebagian tidak melakukan imunisasi secara lengkap, $(44,4 \%)$ da sebagian kecil tidak diberikan ASI eksklusif (27,8\%). Faktor pendapatan keluarga juga berpengaruh terhadap kejadian stunting pada balita (Utami et al., 2019). Hal ini juga dijelaskan dalam beberapa penelitian diantaranya adalah bahwa faktor yang dapat menyebabkan stunting diantaranya adalah pelayanan kesehatan, immunisasi, pengetahuan ibu, pendapatan keluarga, ketersediaan pangan keluarga, dan sanitasi lingkungan (Kusumawati et al., 2013), dari penelitian lain menyebutkan bahwa tingkat asupan energi, riwayat durasi penyakit infeksi, berat badan lahir, 
tingkat pendidikan ibu dan tingkat pendapatan keluargam dengan kejadian stunting.

\section{KESIMPULAN DAN SARAN}

Dari hasil penelitian didapatkan bahwa Pvalue $0,000 \quad(<0,05)$ yang berarti bahwa terdapat pengaruh antara pemberdayaan Pengaruh Pemberdayaan Orangtua Dalam Mengolah Dan Menyusun Menu Makanan terhadap Penambahan Tinggi Badan Anak Penderita Stunting. Dalam mengatasi stunting pada balita, pemberdayaan dengan memberikan pendidikan kesehatan dalam menyiapkan makanan untuk anak stunting terbukti memberi pengaruh terhadap penambahan tinggi badan anak. Intervensi ini tepat dilakukan pada anak dengan stunting.

Meskipun penelitian ini hanya dilakukan dalam tiga bulan. Penelitian ini dapat ditindak lanjuti dengan Gerakan Masyarakat Sadar Gizi Sehat dan Seimbang untuk Mencegah Stunting sehingga peran serta orang tua, keluarga, masyarakat akan sangat membantu dalam menekan laju penderita stunting pada anak. Gerakan tersebut dapat dilaksanakan dengan upaya perbaikan gizi sehat dan seimbang pada anak balita. Sebagaimana diketahui bahwa anakanak merupakan generasi emas penerus bangsa.

\section{DAFTAR PUSTAKA}

Berhe, K., Seid, O., Gebremariam, Y., Berhe, A., \& Etsay, N. (2019). Risk factors of stunting (chronic undernutrition) of children aged 6 to 24 months in Mekelle City, Tigray Region, North Ethiopia: An unmatched case-control study. PLoS ONE, 14(6), 1-11. https://doi.org/10.1371/journal.po ne.0217736

Bloem, M. W., de Pee, S., Hop, L. T., Khan, N. C., Laillou, A., Minarto, Moench-Pfanner, R., Soekarjo, D., Soekirman, Solon, J. A., Theary, C., \& Wasantwisut, E. (2013). Key strategies to further reduce stunting in Southeast Asia: lessons from the ASEAN countries workshop. Food and Nutrition Bulletin, 34(2 Suppl), 8-16. https://doi.org/10.1177/15648265 
130342 s 103

Hanifah, L., Wulansari, R., Meiandayati, R., \& Achadi, E. L. (2018). Stunting trends and associated factors among Indonesian children aged 0-23 months: Evidence from Indonesian Family Life Surveys (IFLS) 2000, 2007 and 2014. Malaysian Journal of Nutrition, 24(3), 315-322.

Hidayat, A. (2012). Tutorial Cara Uji Independent T-Test dengan Excel. Kemenkes, R. I. (2018). Situasi Balita Pendek (Stunting) di Indonesia. Kementeriam Kesehatan RI.

Kusumawati, E., Rahardjo, S., \& Sari, H. P. (2013). Model Pengendalian Faktor Risiko Stunting pada Anak Usia di Bawah Tiga Tahun. Jurnal Kesehatan Masyarakat, 9(3), 249256.

Paudel, R., Pradhan, B., Wagle, R. R., Pahari, D. P., \& Onta, S. R. (2012). Risk factors for stunting among children: A community based case control study in Nepal. Kathmandu University Medical Journal, 10(39), 18-24. https://doi.org/10.3126/kumj.v10i
3.8012

Picauly, I., \& Toy, S. M. (2013). Analisis Determinan Dan Pengaruh Stunting Terhadap Prestasi Belajar Anak Sekolah Di Kupang Dan Sumba Timur, Ntt. Jurnal Gizi Dan Pangan, 8(1), 55. https://doi.org/10.25182/jgp.2013. 8.1.55-62

Rahayu, A., \& Khairiyati, L. (2014). Risiko Pendidikan Ibu Terhadap Kejadian Stunting Pada Anak 6-23 Bulan. Jurnal Penelitian Gizi Makan, 37(2), 129-136.

Reifsnider, E., Shin, C. N., Todd, M., Jeong, M., Gallagher, M., \& Moramarco, M. (2016). How Did They Grow: An Intervention to Reduce Stunted Growth in LowIncome Mexican-American Children. Research in Nursing and Health, 39(2), 105-120. https://doi.org/10.1002/nur.21714 Rockers, P. C., Fink, G., Zanolini, A., Banda, B., Biemba, G., Sullivan, C., Mutembo, S., Silavwe, V., \& Hamer, D. H. (2016). Impact of a community-based package of interventions on child development in Zambia: A cluster- 
randomised controlled trial. $B M J$

Global Health, 1(3).

https://doi.org/10.1136/bmjgh-

2016-000104

Setiawan, E., Machmud, R., \& Masrul,

M. (2018). Faktor-Faktor yang Berhubungan dengan Kejadian

Stunting pada Anak Usia 24-59

Bulan di Wilayah Kerja

Puskesmas Andalas Kecamatan

Padang Timur Kota Padang Tahun

2018. Jurnal Kesehatan Andalas, $7(2)$,

275.

https://doi.org/10.25077/jka.v7i2.

813

Supranto. (2000). Teknik Sampling

untuk Survei dan Eksperimen.

Rineka Cipta.

Timæus, I. M. (2012). Stunting and obesity in childhood: A reassessment using longitudinal data from South Africa.

International Journal of Epidemiology, 41(3), 764-772.

https://doi.org/10.1093/ije/dys026

TNP2K. (2017). Buku saku Desa dalam

Penanganan

Stunting.

Kementerian Desa, Pembangunan

Daerah Tertinggal dan

Transmigrasi.
Unicef. (2013). Improving child nutrition: The Achievable Imperative for Global Progress. United Nations Publications Sales.

Utami, R. A., \& Juliani, E. (2020). Mental, Social-Psychological Stimulation and Nutritional Suplementation Affects Stunting Incidence among Children in Indonesia. Jurnal Kesehatan Holistic, 4(1), 34-51. https://doi.org/10.33377/jkh.v4i1. 72

Utami, R. A., Setiawan, A., \& Fitriyani, P. (2019). Identifying causal risk factors for stunting in children under five years of age in South Jakarta, Indonesia. Enfermeria Clinica, 29, 606-611. https://doi.org/10.1016/j.enfcli.20 19.04.093

Vazir, S., Engle, P., Balakrishna, N., Griffiths, P. L., Johnson, S. L., Creed-Kanashiro, H., Fernandez Rao, S., Shroff, M. R., \& Bentley, M. E. (2013). Cluster-randomized trial on complementary and responsive feeding education to caregivers found improved dietary intake, growth and development 
among rural Indian toddlers.

Maternal and Child Nutrition, 9(1), 99-117.

https://doi.org/10.1111/j.1740-

8709.2012.00413.x

WHO. (2010). Nutrition Landscape

Information System (NLIS)

Country Profile Indicators:

Interpretation guide. Geneva: (p.

38). WORLD Health

Organization.
Widyaningsih, N. N., Kusnandar, K., \& Anantanyu, S. (2018). Keragaman pangan, pola asuh makan dan kejadian stunting pada balita usia 24-59 bulan. Jurnal Gizi Indonesia (The Indonesian Journal of Nutrition), 7(1), 22-29. https://doi.org/10.14710/jgi.7.1.22 $-29$

Wiyono, S. (2015). Buku Ajar Epidemiologi Gizi Konsep dan Aplikasi. Sagung Seto. 